\title{
Assessment of Carbon Sequestration Potential of Mulberry vis-à-vis Soils under Different Cultivation Practices
}

\author{
Vinod Kumar Yadav*, Dhaneshwar Padhan, Sibayan Sen, \\ T. Gayathri, K. Praveen Kumar and Pankaj Tewary
}

Regional Sericultural Research Station, CSRTI, Central Silk Board-Ministry of TextilesGovt. of India, SKLTS Horticultural University Campus Mulugu, Siddipet District, Telangana, India

*Corresponding author

\section{A B S T R A C T}

Keywords

Agro-forestry system, carbon sequestration potential, reduced tillage and mulching

\section{Article Info}

Accepted: 22 December 2019 Available Online: 20 January 2020
Increasing carbon dioxide $\left(\mathrm{CO}_{2}\right)$ content in the atmosphere is the prime cause of global warming. Capturing this $\mathrm{CO}_{2}$ by agro-forestry systems through photosynthetic activity could be one of the ways to reduce its concentration in the atmosphere. Therefore, an attempt was undertaken to fix the atmospheric $\mathrm{CO}_{2}$ employing the mulberry plant as the sink considering its carbon sequestration potential. The experiment was conducted in a red sandy loam soil following conventional practices of mulberry cultivation along with and without reduced tillage and mulching and two levels of irrigation (furrow and drip). The experiment was laid out in split plot design with four different management practices each replicated six times. Initial soil samples before the imposition of treatments and final after harvesting of last crops of third year were collected for analysis of different soil properties and available nutrient status. Results showed that conventional practices with reduced tillage and mulching and drip irrigation improved the soil properties in terms of reducing bulk density, increasing water holding capacity and increase available nutrient status. The carbon sequestration potential (CSP) of mulberry was also found to be higher in the former (15.1 $\mathrm{t} \mathrm{ha}^{-1}$ year $\left.^{-1}\right)$ compared to other management practices. The rate of carbon sequestration $\left(\mathrm{Mg} \mathrm{ha}^{-1} \mathrm{yr}^{-1}\right)$ in soils followed the order of reduced tillage and mulching with drip irrigation (1.33)> reduced tillage and mulching with furrow irrigation (1.03) > conventional practice with drip irrigation $(0.57)>$ conventional practice with furrow irrigation.

\section{Introduction}

Anthropogenic activities associated with rapid industrialization and burning of fuel caused the increase in carbon dioxide $\left(\mathrm{CO}_{2}\right)$ content in the atmosphere crossing the mark of 400 ppm. This increase of $\mathrm{CO}_{2}$ content in the atmosphere is the prime cause of global warming resulting rise in global temperature. To address this problem many developed and developing countries signed the COP21 Paris convention agreement for reducing the 
greenhouse gases and aimed to increase the soil carbon content by 4 per mile with compensation to the greenhouse gas emission. Reducing the carbon foot print by adopting appropriate technologies viz., capturing the atmospheric $\mathrm{CO}_{2}$ and hoarding the carbon in soils could be one of the major components to reduce greenhouse gases emission (Abdullahi et al., 2018; Toochi, 2018.). Agro-forestry systems with woody plants, trees/ shrubs are having the potential for capturing the atmospheric $\mathrm{CO}_{2}$ and convert it to plant biomass by photosynthetic activity. This also helps in sequestration of soil carbon in a long run. Besides sequestration of atmospheric $\mathrm{CO}_{2}$, agro-forestry systems have environmental, financial, and aesthetic benefits (Schoeneberger, 2009). The enhanced C sequestration capacity of agro-forestry systems could be due to the efficient of utilization of resources by the diverse and complex plant communities (Steinbeiss et al., 2008). The capacity to sequester $C$ also varied with plant species being low in slow growing plant species like Shorea robusta, Terminalia tomentosa and Adina cordifolia sequestrate carbon slowly (Mandal et al., 2016). Efficient utilization of resources by the structurally and functionally diverse and complex plant communities in agro-forestry system could enhance the $\mathrm{C}$ sequestration compared to sole crop or grass systems (Thevathasan and Gordon 2004; Steinbeiss et al., 2008).

Carbon sequestration potential of soils varies with soil types, texture, mineralogy, cropping systems followed and intensity of perturbation. Contribution of plant species in sequestration of carbon in soils differ with type of vegetation and age of plants. Perennial vegetation is more effective than annual vegetation as it allocates a higher percentage of $\mathrm{C}$ to belowground and often extends the growing season (Morgan et al., 2010), therefore enhancing $\mathrm{C}$ sequestration potential of agricultural systems even further (Lal et al.,
1998, 1999; Watson et al., 2000; Oelbermann et al., 2006; Jose, 2009). Agro-forestry system accumulates more $\mathrm{C}$ than forests or pastures alone because they have both forest and grassland sequestration and storage patterns (Schroeder 1994; Kort and Turnock 1999; Sharrow and Ismail 2004).

Mulberry is an important component of agroforestry system grown for its leaf over an area of 2.03 lakh hectares in India. Since, mulberry is a C3 plant; it can fix a higher amount of atmospheric $\mathrm{CO}_{2}$ and store in the above ground plant biomass thus, reducing the atmospheric $\mathrm{CO}_{2}$ content simultaneously enriching the soil carbon stock. However, the yield and carbon fixation is regulated by the cultivation strategies followed. We hypothesized that raising mulberry plantation with drip irrigation and reduced tillage followed by mulching could improve the carbon sequestration potential of mulberry visa-vis soils compared to conventional method of cultivation. Therefore, the present investigation was undertaken to study the carbon sequestration potential of mulberry following different cultivation practices.

\section{Materials and Methods}

The study was undertaken in a red sandy loam soil at Central Sericultural Research and Training Institute, Mysore during 2016. The experiment was located at $\mathrm{N} 12^{\circ} 15^{\prime} 41.2^{\prime \prime}$ latitude and $\mathrm{E} \quad 76^{\circ}$ 37' $32.8^{\prime \prime}$ ' longitude experiencing average maximum temperature of between 25.85 to $34.5^{\circ} \mathrm{C}{ }^{\circ} \mathrm{C}$ while minimum temperature 16.1 to $21.5{ }^{\circ} \mathrm{C}$. The average annual rainfall received was between $457 \mathrm{~mm}$ to $1108 \mathrm{~mm}$ with rainy days of 54 days per year.

The experiment was laid out in split plot design with two levels of irrigations i.e. furrow and drip with management practices like with and without reduced tillage and 
mulching along with the recommended package of practices for mulberry cultivation. The treatments were: $\mathrm{T}_{1}$ : conventional practice+ furrow irrigation, $\mathrm{T}_{2}$ : conventional practice+ reduced tillage and mulching+ furrow irrigation, $\mathrm{T}_{3}$ : conventional practice ++ drip irrigation and $\mathrm{T}_{4}$ : conventional practice+ reduced tillage and mulching +drip irrigation. The conventional practice includes application of chemical fertilizers @ NPK:: 350: 140: 140 $\mathrm{kg} / \mathrm{ha} / \mathrm{yr}$ and organic manures viz. farm yard manure @ 25MT/ha/yr. The mulberry variety tested was V1 planted in paired row planting system [(150+90) x $60 \mathrm{~cm}]$ accommodating 13,888 plants/ha. Water addition was quantified for furrow irrigation @ 85,000 gallon per ha in 7 days interval and drip irrigation@2litre/plant/day.

Soil samples at $0.0 .15 \mathrm{~m}$ depth were collected before the initiation of the experiment. Also core samples were taken at the same depth for determination of bulk density of the soils. The soil samples were dried and processed for analysis of various parameters viz., $\mathrm{pH}$, electrical conductivity, organic carbon content, water holding capacity and microbial biomass carbon following standard protocols. Available phosphorus, available potassium and available micronutrients viz. iron, manganese, copper and zinc were analysed by the method outlined by Jackson (1973). The $\mathrm{pH}$, electrical conductivity, bulk density, organic carbon, water holding capacity, microbial biomass carbon, available $\mathrm{P}, \mathrm{K}, \mathrm{Fe}$, $\mathrm{Mn}, \mathrm{Zn}$ and $\mathrm{Cu}$ content of the experimental soil at the initiation of the experimentation were $7.04,0.41 \mathrm{dSm}-1,1.31 \mathrm{Mg} \mathrm{m}-3,5.88 \mathrm{~g}$ kg-1, $15.8 \%, 1.02$ x 10-3 $\mu$ gg-1, 60.3 kg ha- 1 , $373.9 \mathrm{~kg}$ ha-1, $2.53 \mu \mathrm{gg}-1,1.11 \mu \mathrm{gg}-1,2.40$ $\mu \mathrm{gg}-1$ and $0.91 \mu \mathrm{gg}-1$, respectively.

Carbon stock was calculated by considering the bulk density and organic carbon content of the soils. After three years of continuous cultivation with the different management practices, soil samples were collected and analysed for the same parameters in order to study the effect of the management practices on soil properties and carbon stock. Carbon stock in the soils was computed from the following formula.

$\mathrm{C}$ stock in soil $=\mathrm{C}$ content $\times$ Bulk density $\times$ Depth...(1)

Growth characteristics and other yield attributing parameters of mulberry under different cultivation practices were recorded for three years (2016-2018). Mulberry has been cultivated as bush in paired row system of cultivation and annually five crops have been harvested. Carbon sequestration potential (CSP) of mulberry leaf and shoot were calculated by drying the samples at $70^{\circ} \mathrm{C}$ in hot air oven and moisture content was estimated by taking the dry weights of the same. The oven dried leaf and shoot samples were ashed at $550 \mathrm{oC}$ for $6 \mathrm{hr}$ in muffle furnace for estimation of their carbon content (Majumder et al., 2014).

CSP of mulberry was calculated on hectare basis utilizing the dry weights of leaf and shoot moisture content and their respective carbon content as described by Kar et al., (2018).

$\mathrm{CSP}=\mathrm{y} \cdot \mathrm{C} .(100-\mathrm{m}) \cdot 10^{-4} \ldots(2)$

Where, $\mathrm{y}=$ leaf/ shoot yield, $\mathrm{C}=$ leaf/ shoot carbon $\%, \mathrm{~m}=$ leaf/ shoot moisture $\%$.

\section{Results and Discussion}

Changes in soil properties due to application of two levels of irrigation with or without reduced tillage and mulching over the years (2016-2018)

Results depicted in table. 1 showed that the initial $\mathrm{pH}$ of the experimental plot was 7.04 
which reduced in all the treatments over the years. This might be because of the application of acid producing chemical fertilizers (ammonium sulphate). The magnitude of decrease was more in $T_{4}$ followed by $\mathrm{T}_{2}$. The possible reason ascribed for these could be because of organic acids released from the decomposition of mulching materials in both the treatments. The initial electrical conductivity ( $\mathrm{dS} \mathrm{\textrm {m } ^ { - 1 }}$ ) was found to be 0.41 which increased in all the treatments over the years. This could be because of addition of water soluble salts through application of chemical fertilizers (ammonium sulphate, single super phosphate and muriate of potash). Bulk density $\left(\mathrm{Mg} \mathrm{m}^{-3}\right)$ of soils at the initiation of experiment was 1.31 which reduced in all the treatments. Increased organic carbon content in all the treatments could reduce the bulk density and improved soil structure. Similarly the water holding capacity (\%) of initial soil was 15.8 ; which on cultivation of mulberry over the years with drip and furrow irrigations with or without reduced tillage and mulching improved. Again this could be possible because of increased organic carbon content in all the treatments which improved the soil structure by forming water stable aggregates that could hold water to a greater extent. Organic carbon (g kg-1) content of initial soil was 5.88 and it was found to be increased in all the treatments over the years. Higher biomass production with application of chemical fertilizers could increase the carbon content in the root rhizosphere due to rhizodeposition. The magnitude of increase was higher in reduced tillage with mulching in both furrow as well as drip irrigation treatments compared to treatments without reduced tillage and mulching. Microbial biomass carbon (x $10^{-3}$ $\mu \mathrm{g} g-1)$ was increased in all the treatments over the years compared to initial. This may be correlated with increased organic carbon content in respective treatments. Shahid et al., (2014) reported that reduced tillage and mulching with poultry manure could improve the soil properties and grain yield of sorghum.

The collected soil samples were analysed for available macro $(\mathrm{P} \& \mathrm{~K}$ ) and micro-nutrients (Fe, $\mathrm{Mn}, \mathrm{Zn} \& \mathrm{Cu}$ ). The available $\mathrm{P}$ content in soils increased due to management practices compared to its initial status indicating a small build up in $\mathrm{P}$ in soils due to application of $\mathrm{P}$ containing chemical fertilizer (Single superphosphate). Available $\mathrm{K}\left(\mathrm{kg} \mathrm{ha}^{-1}\right)$ in initial soil was found to be 373.9 which reduced in all treatments except $\mathrm{T}_{4}$ over the years (table. 2). The depletion from initial status despite of application of potassic fertilizer could be attributed to the fact that the higher crop removal because of higher biomass production and leaching losses from soils. However, $\mathrm{T}_{4}$ could able to maintain the available potassium content in soils which might be because of improved use efficiency in drip irrigated condition reducing leaching loss and increased the available $K$ content in soil. Similar findings reported by Harisha et al., (2017) in fenugreek. A decreasing trend in available micronutrients ( $\mathrm{Fe}, \mathrm{Mn}, \mathrm{Zn}$ and $\mathrm{Cu}$ ) content in treatment without reduced tillage and mulching was noticed compared to their respective initial amounts in soils. Reduced tillage with inclusion of cover mulch increased the organic carbon content in the experimental soils. Thus, despite of higher crop removal of micronutrients (Fe, $\mathrm{Mn}, \mathrm{Zn}$ and $\mathrm{Cu}$ ), $\mathrm{T}_{2}$ and $\mathrm{T}_{4}$ could maintain higher amount compared to initial (except in case of available Mn).

\section{Growth and yield parameters of mulberry due to cultivation practices over the years}

The results on growth and yield parameters of mulberry was analysed statistically and were presented in table 3, $4 \& 5$. During the period of three years, fifteen crops were harvested and growth parameters were recorded as per schedule. 
Effect of two levels of irrigation (drip and furrow) with and without reduced tillage and mulching on growth parameters and yield of mulberry during 2016

Results depicted in table. 3 showed that the average plant height $(\mathrm{cm})$ and longest shoot length were high in $\mathrm{T}_{4}$ compared to other treatments. This was true for no. of leaves per shoot, leaf area, moisture content and moisture retention capacity and leaf yield. The possible reason for such improved growth parameters and leaf yield of mulberry could be correlated with the high nutrient availability for growth and development and improved soil properties in $\mathrm{T}_{4}$. Higher yield and improved growth of field crops in drip irrigation and reduced tillage with mulching were reported by many researchers (Thierfelder et al., 2013; Assefa et al., 2019). However, no. of shoots per plant and leaf: shoot ratio was similar in both $\mathrm{T}_{2}$ and $\mathrm{T}_{4}$ treatments.

Effect of two levels of irrigation (drip and furrow) with and without mulching and reduced tillage on growth parameters and yield of mulberry during 2017

The average plant height $(\mathrm{cm})$ was high in $\mathrm{T}_{4}$ compared to other treatments (table. 4). This was true for no. of shoots per plant, no. of leaves per shoot, leaf area, moisture content and moisture retention capacity and leaf yield. The possible reason for such improved growth parameters and leaf yield of mulberry could be correlated with the high nutrient availability for growth and development and improved soil properties in $\mathrm{T}_{4}$. Higher yield and improved growth of field crops in drip irrigation and reduced tillage with mulching were reported by many researchers (Thierfelder et al., 2013; Assefa et al., 2019).
However, the longest shoot length $(\mathrm{cm})$ and leaf: shoot ratio was similar in both $\mathrm{T}_{2}$ and $\mathrm{T}_{4}$ treatments.

Effect of two levels of irrigation (drip and furrow) with and without mulching and reduced tillage on growth parameters and yield of mulberry during 2018

Results depicted in table.5 showed that the average plant height $(\mathrm{cm})$ and longest shoot length were high in $\mathrm{T}_{4}$ compared to other treatments. This was true for leaf area, moisture content and leaf yield. The possible reason for such improved growth parameters and leaf yield of mulberry could be correlated with the high nutrient availability for growth and development and improved soil properties in T4. Higher yield and improved growth of field crops in drip irrigation and reduced tillage with mulching were reported by many researchers (Thierfelder et al., 2013; Assefa $e t$ al., 2019). However, the no. of shoots per plant, no. of leaves per shoot, leaf: shoot ratio and moisture retention capacity were almost similar in both $\mathrm{T}_{2}$ and $\mathrm{T}_{4}$ treatments.

\section{Carbon Sequestration Potential of Mulberry}

Carbon sequestration potential (CSP) of mulberry was calculated taking into consideration the moisture content, carbon content in plant tissue and yield of leaf and stems. The CSP of mulberry for each crop was determined and pooled together and annual CSP of mulberry was presented in table. 6 and Fig.1. In first year CSP $\left(\mathrm{t} \mathrm{ha}^{-1}\right)$ of mulberry was high in $T_{4}$ and low in $T_{1}$. Similar results were also recorded in second and third year. On average, the CSP $\left(\mathrm{t} \mathrm{ha}^{-1}\right)$ of mulberry in $\mathrm{T}_{4}$ was higher compared to other treatments. 
Table.1 Effect of two levels of irrigation (drip and furrow) with and without reduced tillage and mulching on soil physical, chemical and biological properties

\begin{tabular}{|c|c|c|c|c|c|c|}
\hline Treatment & $\mathrm{pH}$ & $\begin{array}{c}\mathrm{EC} \\
\left(\mathrm{dSm}^{-1}\right)\end{array}$ & $\begin{array}{c}\mathrm{OC} \\
\left(\mathrm{gkg}^{-1}\right)\end{array}$ & $\begin{array}{c}\mathrm{BD} \\
\left(\mathrm{Mgm}^{-3}\right)\end{array}$ & $\begin{array}{c}\text { WHC } \\
(\%)\end{array}$ & $\begin{array}{c}\text { Microbial Biomass } \\
\text { Carbon } \\
\left(\mathrm{x} \mathrm{10}^{-3} \mu \mathrm{gg}^{-1}\right)\end{array}$ \\
\hline $\mathrm{T}_{1}$ & 6.90 & 0.54 & 6.63 & 1.27 & 17.7 & 1.26 \\
\hline $\mathrm{T}_{2}$ & 6.80 & 0.50 & 7.83 & 1.25 & 19.8 & 1.63 \\
\hline $\mathrm{T}_{3}$ & 6.83 & 0.53 & 7.07 & 1.25 & 18.7 & 1.38 \\
\hline $\mathrm{T}_{4}$ & 6.72 & 0.49 & 8.52 & 1.22 & 21.8 & 1.69 \\
\hline Initial & 7.04 & 0.41 & 5.88 & 1.31 & 15.8 & 1.02 \\
\hline $\mathrm{SEm} \pm$ & 0.06 & 0.27 & 0.38 & 0.66 & 1.28 & 0.12 \\
\hline $\mathrm{CD}(\mathrm{P}<0.05)$ & 0.15 & 0.82 & 1.20 & $\mathrm{NS}$ & 3.98 & 0.40 \\
\hline
\end{tabular}

Table.2 Effect of two levels of irrigation (drip and furrow) with and without reduced tillage and mulching on available macro and micronutrient contents of soil

\begin{tabular}{|c|c|c|c|c|c|c|}
\hline Treatment & $\begin{array}{c}\text { Avail. P } \\
\left(\mathrm{kgha}^{-1}\right)\end{array}$ & $\begin{array}{c}\text { Avail. K } \\
\left(\mathrm{kgha}^{-1}\right)\end{array}$ & $\begin{array}{c}\text { Avail. Fe } \\
\left(\mu g^{-1}\right)\end{array}$ & $\begin{array}{c}\text { Avail. Mn } \\
\left(\mu g^{-1}\right)\end{array}$ & $\begin{array}{c}\text { Avail. Cu } \\
\left(\mu g^{-1}\right)\end{array}$ & $\begin{array}{c}\text { Avail. Zn } \\
\left(\mu g^{-1}\right)\end{array}$ \\
\hline $\mathrm{T}_{1}$ & 66.5 & 316.1 & 1.90 & 0.79 & 0.63 & 1.41 \\
\hline $\mathrm{T}_{2}$ & 70.4 & 360.3 & 3.18 & 1.06 & 0.96 & 3.17 \\
\hline $\mathrm{T}_{3}$ & 68.9 & 345.8 & 1.97 & 0.80 & 0.69 & 1.73 \\
\hline $\mathrm{T}_{4}$ & 72.2 & 407.8 & 3.25 & 1.30 & 1.10 & 3.30 \\
\hline Initial & 60.3 & 373.9 & 2.53 & 1.11 & 0.91 & 2.40 \\
\hline $\mathrm{SEm} \pm$ & 3.66 & 6.89 & 1.40 & 0.53 & 0.46 & 1.34 \\
\hline $\mathrm{CD}(\mathrm{P}<0.05)$ & 11.12 & 20.74 & 4.24 & 1.62 & 1.39 & 4.07 \\
\hline
\end{tabular}

Table.3 Effect of two levels of irrigation (drip and furrow) with and without reduced tillage and mulching on growth parameters and yield of mulberry during 2016 (average and pooled data of five crops)

\begin{tabular}{|c|c|c|c|c|c|c|c|c|c|}
\hline Treatments & $\begin{array}{c}\text { Plant } \\
\text { height } \\
(\mathrm{cm})\end{array}$ & $\begin{array}{c}\text { Longest } \\
\text { shoot } \\
\text { length } \\
(\mathrm{cm})\end{array}$ & $\begin{array}{c}\text { No. of } \\
\text { shoots/ } \\
\text { plant }\end{array}$ & $\begin{array}{c}\text { No. of } \\
\text { leaves/ } \\
\text { shoot }\end{array}$ & $\begin{array}{c}\text { Leaf } \\
\text { area } \\
\left(\mathrm{cm}^{2}\right)\end{array}$ & $\begin{array}{c}\text { Leaf : } \\
\text { shoot } \\
\text { ratio }\end{array}$ & $\begin{array}{c}\text { Moisture } \\
\text { content } \\
(\%)\end{array}$ & $\begin{array}{c}\text { Moisture } \\
\text { retention } \\
\text { capacity } \\
(\%)\end{array}$ & $\begin{array}{c}\text { Leaf } \\
\text { Yield } \\
\left(\text { t ha }^{-}\right. \\
\left.\text {year }^{-1}\right)\end{array}$ \\
\hline $\mathrm{T}_{1}$ & 161.2 & 162.0 & 7.6 & 26.3 & 159.2 & 1.4 & 72.4 & 72.0 & 55.9 \\
\hline $\mathrm{T}_{2}$ & 174.2 & 175.2 & 8.3 & 29.6 & 170.5 & 1.5 & 73.9 & 73.5 & 63.0 \\
\hline $\mathrm{T}_{3}$ & 170.4 & 171.2 & 8.1 & 28.4 & 165.8 & 1.4 & 73.4 & 72.8 & 60.6 \\
\hline $\mathrm{T}_{4}$ & 175.7 & 177.0 & 8.3 & 30.4 & 171.9 & 1.5 & 74.2 & 73.8 & 63.7 \\
\hline $\mathrm{SEm} \pm$ & 1.51 & 1.35 & 0.06 & 0.35 & 1.16 & 0.01 & 0.24 & 0.18 & 2.34 \\
\hline $\mathrm{CD}(\mathrm{P}<0.05)$ & 4.57 & 4.10 & 0.18 & 1.07 & 3.53 & 0.03 & 0.73 & 0.59 & 7.24 \\
\hline
\end{tabular}


Table.3 Effect of two levels of irrigation (drip and furrow) with and without reduced tillage and mulching on growth parameters and yield of mulberry during 2016 (average and pooled data of five crops)

\begin{tabular}{|c|c|c|c|c|c|c|c|c|c|}
\hline Treatments & $\begin{array}{c}\text { Plant } \\
\text { height } \\
(\mathrm{cm})\end{array}$ & $\begin{array}{c}\text { Longest } \\
\text { shoot } \\
\text { length } \\
(\mathrm{cm})\end{array}$ & $\begin{array}{c}\text { No. of } \\
\text { shoots/ } \\
\text { plant }\end{array}$ & $\begin{array}{c}\text { No. of } \\
\text { leaves/ } \\
\text { shoot }\end{array}$ & $\begin{array}{c}\text { Leaf area } \\
\left(\mathrm{cm}^{2}\right)\end{array}$ & $\begin{array}{c}\text { Leaf : } \\
\text { shoot ratio }\end{array}$ & $\begin{array}{c}\text { Moisture } \\
\text { content } \\
(\%)\end{array}$ & $\begin{array}{c}\text { Moisture } \\
\text { retention } \\
\text { capacity } \\
(\%)\end{array}$ & $\begin{array}{c}\text { Leaf Yield } \\
\left(\mathrm{t} \text { ha }{ }^{-1} \text { year }\right.\end{array}$ \\
\hline $\left.\mathrm{T}_{1}{ }^{-1}\right)$
\end{tabular}

Table.4 Effect of two levels of irrigation (drip and furrow) with and without reduced tillage and mulching on growth parameters and yield of mulberry during 2017 (average and pooled data of five crops)

\begin{tabular}{|c|c|c|c|c|c|c|c|c|c|}
\hline Treatments & $\begin{array}{l}\text { Plant } \\
\text { height } \\
(\mathrm{cm})\end{array}$ & $\begin{array}{c}\text { Longest } \\
\text { shoot } \\
\text { length } \\
(\mathrm{cm})\end{array}$ & $\begin{array}{l}\text { No. of } \\
\text { shoots/ } \\
\text { plant }\end{array}$ & $\begin{array}{c}\text { No. of } \\
\text { leaves/ } \\
\text { shoot }\end{array}$ & $\begin{array}{l}\text { Leaf area } \\
\left(\mathrm{cm}^{2}\right)\end{array}$ & $\begin{array}{c}\text { Leaf: } \\
\text { shoot ratio }\end{array}$ & $\begin{array}{l}\text { Moisture } \\
\text { content } \\
(\%)\end{array}$ & $\begin{array}{c}\text { Moisture } \\
\text { retention } \\
\text { capacity } \\
(\%)\end{array}$ & $\begin{array}{l}\text { Leaf Yield } \\
\left(\mathrm{t} \mathrm{ha}^{-1} \text { year }^{-1}\right)\end{array}$ \\
\hline $\mathrm{T}_{1}$ & 158.2 & 159.1 & 7.6 & 24.6 & 157.6 & 1.4 & 71.9 & 71.5 & 55.7 \\
\hline $\mathrm{T}_{2}$ & 175.2 & 178.2 & 8.4 & 30.5 & 171.4 & 1.5 & 74.6 & 73.8 & 64.7 \\
\hline $\mathrm{T}_{3}$ & 170.1 & 171.6 & 8.2 & 28.8 & 166.0 & 1.4 & 73.3 & 73.1 & 60.9 \\
\hline $\mathrm{T}_{4}$ & 176.1 & 178.8 & 8.5 & 31.4 & 172.0 & 1.5 & 75.0 & 74.1 & 65.4 \\
\hline SEm \pm & 1.70 & 1.24 & 0.02 & 0.43 & 1.45 & 0.01 & 0.17 & 0.19 & 3.10 \\
\hline $\mathrm{CD}(\mathrm{P}<0.05)$ & 5.14 & 3.75 & 0.06 & 1.30 & 4.40 & 0.02 & 0.51 & 0.59 & 9.40 \\
\hline
\end{tabular}


Table.5 Effect of two levels of irrigation (drip and furrow) with and without reduced tillage and mulching on growth parameters and yield of mulberry during 2018 (average and pooled data of five crops)

\begin{tabular}{|c|c|c|c|c|c|c|c|c|c|}
\hline Treatments & $\begin{array}{l}\text { Plant } \\
\text { height } \\
(\mathrm{cm})\end{array}$ & $\begin{array}{l}\text { Longest } \\
\text { shoot } \\
\text { length } \\
(\mathrm{cm})\end{array}$ & $\begin{array}{c}\text { No. of } \\
\text { shoots/ } \\
\text { plant }\end{array}$ & $\begin{array}{l}\text { No. of } \\
\text { leaves/ } \\
\text { shoot }\end{array}$ & $\begin{array}{l}\text { Leaf area } \\
\quad\left(\mathrm{cm}^{2}\right)\end{array}$ & $\begin{array}{c}\text { Leaf : } \\
\text { shoot ratio }\end{array}$ & $\begin{array}{c}\text { Moisture } \\
\text { content } \\
(\%)\end{array}$ & $\begin{array}{c}\text { Moisture } \\
\text { retention } \\
\text { capacity } \\
(\%)\end{array}$ & $\begin{array}{l}\text { Leaf Yield } \\
\left(\mathrm{t} \mathrm{ha}^{-1} \text { year }^{-1}\right)\end{array}$ \\
\hline $\mathrm{T}_{1}$ & 161.2 & 162.0 & 7.6 & 26.3 & 159.2 & 1.4 & 72.4 & 72.0 & 55.9 \\
\hline $\mathrm{T}_{2}$ & 174.6 & 175.2 & 8.3 & 29.6 & 170.5 & 1.5 & 73.9 & 73.5 & 62.9 \\
\hline $\mathrm{T}_{3}$ & 170.4 & 171.2 & 8.2 & 28.9 & 165.8 & 1.4 & 73.6 & 72.8 & 60.6 \\
\hline $\mathrm{T}_{4}$ & 175.3 & 177.0 & 8.3 & 29.9 & 171.9 & 1.5 & 74.0 & 73.7 & 63.7 \\
\hline SEm \pm & 1.53 & 1.35 & 0.06 & 0.48 & 1.16 & 0.01 & 0.28 & 0.21 & 2.54 \\
\hline $\mathrm{CD}(\mathrm{P}<0.05)$ & 4.63 & 4.10 & 0.18 & 1.45 & 3.53 & 0.03 & 0.84 & 0.64 & 7.28 \\
\hline
\end{tabular}


Table.6 Effect of two levels of irrigation (drip and furrow) with and without reduced tillage and mulching on carbon sequestration potential of mulberry stem and leaf $\left(\mathrm{t} \mathrm{ha}^{-1}\right.$ year $\left.^{-1}\right)$

\begin{tabular}{|c|c|c|c|c|}
\hline Treatments & First year & Second year & Third year & Average \\
\hline $\mathrm{T}_{1}$ & 13.2 & 12.8 & 13.6 & 13.2 \\
\hline $\mathrm{T}_{2}$ & 14.4 & 15.2 & 13.6 & 14.4 \\
\hline $\mathrm{T}_{3}$ & 13.2 & 14.8 & 14.6 & 14.2 \\
\hline $\mathrm{T}_{4}$ & 14.9 & 15.6 & 14.8 & 15.1 \\
\hline $\mathrm{SEm} \pm$ & 0.38 & 0.91 & 0.38 & - \\
\hline $\mathrm{CD}(\mathrm{P}<0.05)$ & 1.44 & 2.72 & 1.24 & - \\
\hline
\end{tabular}

Table.7 Effect of two levels of irrigation (drip and furrow) with and without reduced tillage and mulching on carbon stock, amount of $\mathrm{C}$ sequestered and rate of $\mathrm{C}$ sequestration in soil

\begin{tabular}{|c|c|c|c|c|}
\hline Treatments & $\begin{array}{c}\text { Organic carbon } \\
\left(\mathrm{gkg}^{-1}\right)\end{array}$ & $\begin{array}{c}\text { Carbon stock } \\
\left(\mathrm{Mg} \mathrm{ha}^{-1}\right)\end{array}$ & $\begin{array}{c}\text { C Sequestrated } \\
\left(\mathrm{Mg} \mathrm{ha}^{-1}\right)\end{array}$ & $\begin{array}{c}\text { Rate of C } \\
\text { sequestration } \\
\left(\mathrm{Mg} \mathrm{ha}^{-1} \mathrm{yr}^{-1}\right)\end{array}$ \\
\hline Initial & 5.88 & 11.5 & - & - \\
\hline $\mathrm{T}_{1}$ & 6.63 & 12.6 & 1.09 & 0.36 \\
\hline $\mathrm{T}_{2}$ & 7.83 & 14.6 & 3.08 & 1.03 \\
\hline $\mathrm{T}_{3}$ & 7.07 & 13.3 & 1.71 & 0.57 \\
\hline $\mathrm{T}_{4}$ & 8.52 & 15.5 & 4.00 & 1.33 \\
\hline $\mathrm{SEm} \pm$ & 0.38 & 0.85 & 0.94 & 0.28 \\
\hline $\mathrm{CD}(\mathrm{P}<0.05)$ & 1.20 & 2.50 & 2.57 & 0.96 \\
\hline
\end{tabular}

Fig.1 Carbon Sequestration potential of mulberry influenced by management practices

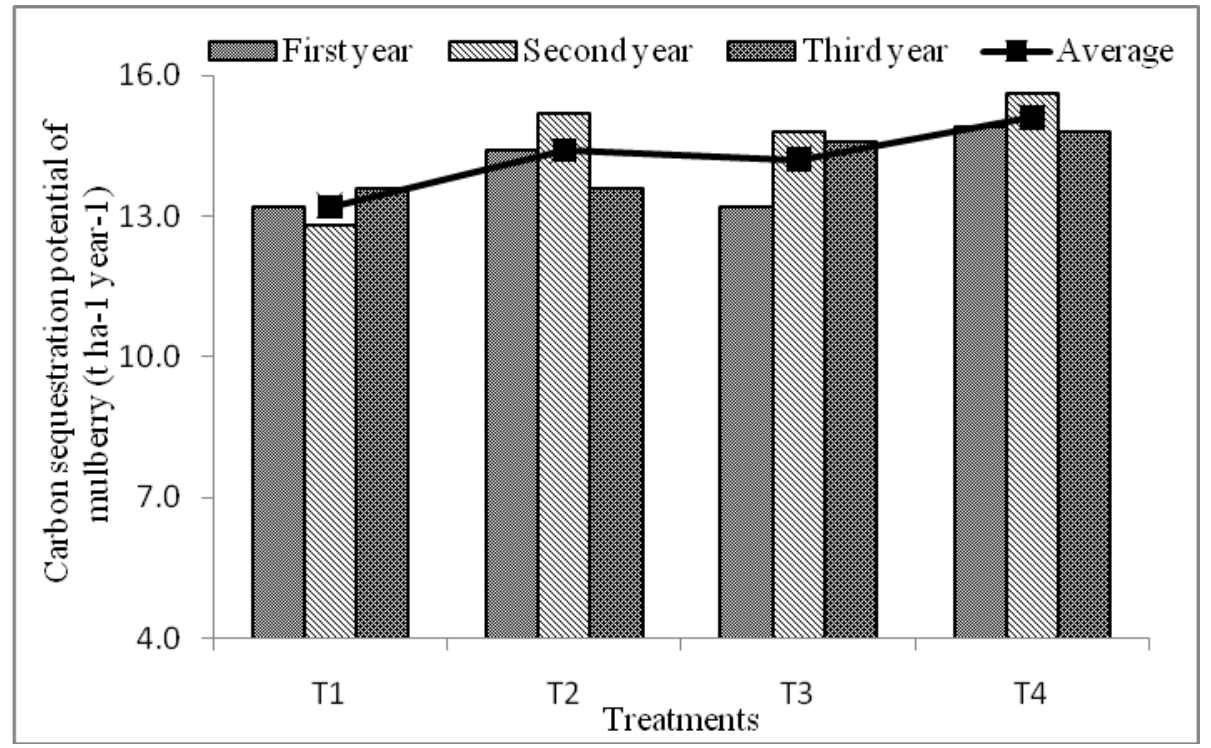


This could be possibly because of higher yield of mulberry and nutrition in the said treatment which improved the growth attributes signalling for higher sequestration potential of carbon. Kar et al., (2018) reported that mulberry growing under moderate tillage with grass cover registered the highest leaf productivity and CSP of $38.72 \mathrm{t} \mathrm{ha}^{-1}$ year $^{-1}$ and $6.90 \mathrm{t} \mathrm{ha}^{-1}$ year $^{-1}$, respectively in comparison to the existing farming practice (IT) registering the same two parameters as $38.16 \mathrm{t}$ $\mathrm{ha}^{-1}$ year $^{-1}$ and $6.54 \mathrm{t} \mathrm{ha}^{-1}$ year $^{-1}$, respectively.

\section{Carbon stock, amount of $\mathrm{C}$ sequestered and rate of $C$ sequestration in soil}

Crop management practices had a considerable effect on carbon stock, amount of carbon sequestered and also the rate of $\mathrm{C}$ sequestration in soil. A higher amount of $\mathrm{C}$ was sequestered in $\mathrm{T}_{4}$ treatment compared to other treatments (table.7). Similarly a higher value was found with $\mathrm{T}_{2}$ treatment. This could be possibly because of addition of crop residues followed by least disturbance in terms of reduced tillage which could maintain a higher carbon stock and subsequently a higher amount of sequestered $\mathrm{C}$ in soils.

The rate of $\mathrm{C}$ sequestration was also high in $\mathrm{T}_{4}$ followed by $T_{2}$. The lowest rate of $C$ sequestration was noticed in $\mathrm{T}_{1}$ which can be attributed to the fact that intensive tillage could disturb the allocation of $\mathrm{C}$ into different long-lived pools and concurrently reduced its storage potential in soils. Organic amendments like animal and poultry manures, the incorporation of different crop residues, different types of compost, sugarcane bagasse, peat soils, different wood chips, biochar vis-avis good agricultural practices like cover crops, nutrient management, mulching, zero and no-tillage techniques, soil biota management and mulching could enhance the soil organic matter and improve the soil's physical and chemical properties which help to sequester more $\mathrm{C}$ in soil which ultimately contributes towards carbon sequestration (Farooqi et al., 2018).

In the present study, among the cultivation and irrigation practices tested, reduced tillage with mulching and drip irrigation resulted improved soil properties in terms of maintaining its available nutrient status and other physical, chemical and biological properties of soil. The management practices also resulted higher biomass yield and improved other yield contributing attributes. In terms of carbon sequestration potential of mulberry as well carbon stock and rate of $\mathrm{C}$ sequestration in soil, reduced tillage with mulching and drip irrigation recorded higher value compared to other management practices.

\section{Acknowledgment}

The author is thankful to Central Silk Board for funding to carry out the work at Central Sericultural Research \&Training Institute, Mysore.

\section{References}

Abdullahi, A.C., Siwar, C., Ismail, M.S. and Anizan, I. 2018. Carbon Sequestration in Soils: The Opportunities and Challenges. DOI: 10.5772/intechopen.79347.

Assefa, T., Jha, M., Reyes, M., Seifu, T. and Worglul, A.W. 2019. Experimental Evaluation of Conservation Agriculture with Drip Irrigation for Water Productivity in Sub-Saharan Africa. Water. 11(3): 530; https://doi.org/10.3390/w1103053 0 .

Farooqi, Z.U.R. Sabir, M., Zeeshan, N., Naveed, K. and Hussain, M.M. 2018. Enhancing Carbon Sequestration Using Organic Amendments and 
Agricultural Practices. DOI: 10.5772/intechopen.79336.

Harisha, C.B., Asangi, H. and Singh, R. 2017. Impact of Drip Irrigation and Fertigation on Residual Soil Nutrient Status, Nutrient Uptake and Nutrient Use Efficiency of Fenugreek under Semi Arid Conditions, Int. J. Pure App. Biosci. 5(2): 661-667. doi: http://dx.doi.org/10.18782/23207051.2625

Jose, S. 2009. Agroforestry for ecosystem services and environmental benefits: an overview. Agrofor Syst. 76:1-10.

Kar, R., Vijay, V. and Trivedy, K. 2018. Comparative performance of farming practices in terms of carbon sequestration potential of mulberry and soil organic carbon stock. Journal of Soil Science and Environmental Management. 9(10): 147-153. DOI: 10.5897/JSSEM2018.0697.

Kort, J. and Turnock, R. 1999. Carbon reservoir and biomass in Canadian prairie shelterbelts. Agrofor Syst. 44:175-186.

Lal, R., Kimble, J.M., Follett, R.F. and Cole, C.V. 1998. The potential for U.S. crop land to sequester carbon and mitigate the greenhouse effect. Ann Arbor Press, Chelsea

Lal, R., Kimble, J.M., Follett, R.F. and Cole, C.V. 1999. Managing U.S. cropland to sequester carbon in soils. J Soil Water Conserv. 54:374-381.

Majumder, S.K., Kar, R. and Bindroo, B.B. 2014. A study on carbon assimilation by mulberry plant under nutrient management system. Abstracts: National Conference on Sericulture for Livelihood Security, University of Agricultural Sciences, Bangalore, College of Sericulture, Chintamani P 32.

Mandal, R.A., Jha, P.K., Dutta, I.C., Thapa, U. and Karmacharya, S.B. 2016. Carbon sequestration in tropical and subtropical plant species in collaborative and community forests of Nepal. Advances in Ecology. http://dx.doi.org/10.1155/2016/152970 3.

Morgan, J.A., Follett, R.F., Allen, L.H., Grosso, S.D., Derner, J.D., Dijkstra, F., Franzluebbers, A., Fry, R., Paustian, K. and Schoeneberger, M.M. 2010. Carbon sequestration in agricultural land of the United States. J Soil Water Conserv. 65:6A-13A.

Oelbermann, M., Voroney, R.P., Kass, D.C.L. and Schlonvoigt, A.M. 2006. Soil carbon and nitrogen dynamics using stable isotopes in 19- and 10-yr old tropical agroforestry systems. Geoderma. 130:356-367.

Schoeneberger, M.M. 2009. Agroforestry: working trees for sequestering carbon on agricultural lands. Agrofor Syst. 75:27-37.

Schroeder, P. 1994. Carbon storage benefits of agroforestry systems. Agrofor Syst. 27:89-97.

Shahid, M., Zamir, S., Rasool, T. And Akbar, W. 2014. Effect of Tillage and Mulching on Soil Fertility and Grain Yield of Sorghum. Sci. Agri. 4 (1):3136.

Sharrow, S.H. and Ismail, S. 2004. Carbon and nitrogen storage in agroforests, tree plantations, and pastures in western Oregon, USA. Agrofor Syst. 60:123-130.

Steinbeiss, S., Bebler, H., Engels, C., Temperton, V.M., Buchmanns, N., Roscher, C., Kreutziger, Y., Baade, J., Habekost, M. and Gleixner, G. 2008. Plant diversity positively affects shortterm soil carbon storage in experimental grasslands. Glob Clim Biol. 14:2937-2949.

Thevathasan, N.V. and Gordon, A.M. 2004. Ecology of tree intercropping systems 
in the north temperate region: experiences from southern Ontario, Canada. Agrofor Syst. 61:257-268.

Thierfelder, C., Mwila, M. and Rusinamhodzi, L. 2013. Conservation agriculture in eastern and southern provinces of Zambia: Long-term effects on soil quality and maize productivity. Soil Tillage Res. 126: 246-258.

Toochi, E.C. 2018. Carbon sequestration: how much can forestry sequester CO2? Forest Res Eng Int J. 2(3):148-150. Watson, R.T., Noble, I.R., Bolin, B., Ravindranathan, N.R., Verardo, D.J. and Dokken, D.J. 2000. IPCC special report on land use, land use change, and forestry. Intergovernmental panel on climate change. http://www.rida.no/climate/ipcc/land_u $\mathrm{se} /$.

\section{How to cite this article:}

Vinod Kumar Yadav, Dhaneshwar Padhan, Sibayan Sen, T. Gayathri, K. Praveen Kumar and Pankaj Tewary. 2020. Assessment of Carbon Sequestration Potential of Mulberry vis-à-vis Soils under Different Cultivation Practices. Int.J.Curr.Microbiol.App.Sci. 9(01): 2463-2474. doi: https://doi.org/10.20546/ijcmas.2020.901.281 